\title{
Teachers' Opinions on Alternative Approaches in Social Studies Education: Poetry and Music Module
}

\author{
Ahmet Durmaz \\ Nevşehir Haci Bektaş Veli University, Education Faculty, Nevşehir, TURKEY
}

Received: 4 May 2020 • Accepted: 8 July 2020 • Published Online: 20 July 2020

\begin{abstract}
There are many methods and techniques used in social studies education. Some of them are good guides for students in the subjects which they want to learn, but others cannot. Therefore, alternative methods should be used in order to understand the social studies lesson better for students. Poetry and music are some of these alternative forms. In terms of applicability of this method, opinions of teachers of social studies working in various middle schools in Nevssehir province were taken. Qualitative data collection tools were used in the research and descriptive and content analysis methods were used in the analysis of qualitative data. A semi-structured interview form prepared by field experts was used as data collection tool. In addition, other field experts have been consulted for the validity of the form. The data were analyzed using descriptive and content analysis methods. Categorical analysis technique was used in content analysis. In addition, internal reliability of the questionnaire was increased by quantifying qualitative data by making direct citations from the interviews, and by giving examples from teacher opinions about the questions, it was aimed to explain the opinions of the teachers better. The opinions of the teachers, the applicability of poetry and music to social studies course has been put forward. Studies and findings show that teachers' opinions on the use of poetry and music in social studies are positive.
\end{abstract}

Keywords: teachers, social studies, module, music, poetry.

\section{Introduction}

Since poetry and music first appeared, it has always attracted people's attention. People tried to express their thoughts and feelings through music or poetry. In the Turkish poetry, religious issues were first covered. However, later on, poems related to different topics were written (Yardimc1, 1999: 16). Poetry is a branch of art that helps to understand and explain the world. Poetry is often seen as something central and necessary for human existence (Donaldson, 2001: 25; Arp, 1997). Poetry can show human reactions to historical or contemporary events, historical complexities and the common consciousness of an era (Meadows, 1999). Information about the world can offer unique information and explanations that increase our understanding and awareness in the world (Donaldson, 2001: 25). Poetry is a tool used rhythmically to stimulate people's emotions. With this feature, it is connected with music. Music is a tool that people use in every period from birth to death. Music has been seen as a major factor in the education and purification of the soul. Pythagoras, Plato, Aristotle and Boethius, who made important contributions to music during the period, found a place in the music with the written tragedies, metaphors in his works and experimental studies and argued that it was a fact that should be kept

(C) Authors. Terms and conditions of Creative Commons Attribution 4.0 International (CC BY 4.0) apply. Correspondence: Ahmet Durmaz (Assist. Prof. Dr.), Nevşehir Haci Bektaş Veli University, Education Faculty, Nevşehir, TURKEY. E-mail: ahmtdrmz50@gmail.com. 
alive (Kutlu, 2019: 300). Music education that children will receive at a young age will provide them with convenience in developing and educating life perception, interpretation, creativity and thinking system. If children are fed with music that suits them psychologically and physiologically from a young age, they will be individuals who love, choose and know how to use it when they grow up (Şen, 2010: 342). Also, parents assume that music is essential for their children's healthy psychological development (Bağrıç̧ı, 2019). Therefore, it is an acceptable assumption that a rich music education to be given at a young age will help children develop their understanding of music and abilities, as well as facilitating the reason for the problems and events they will encounter. In addition, music is an expression of mental processes (Akkaş 1993: 11-12). Especially classical music has a relaxing effect on children. It is known that the works of W. A. Mozart, one of the known names of classical music, have an impact on children (Yöre, 2004: 38). In his book, Tanrlkorur (2003) stated that, according to the views of some ministers of the period, introducing Turkish music into schools would prevent our development and we could not be modernized. However, students can be given a very good education by using Turkish music in education. That is why alternative approaches exist. In addition, many poems contain at least one of the ten thematic areas of social sciences (McCall, 2004: 173). Since poetry is shorter than other literary texts, it can be read more quickly in the lesson and can be a more interesting material, far from boring of a textbook. With openness, focus, rich words, emotions, imagination and various perspectives, poetry is complementary rather than primary source for social studies (Vardell, 2003: 209). Poets are important because they can gain more understanding and awareness from the world. Therefore, it makes sense to expect poetry to create a window in which students can clarify their world views (Arp, 1997: 4). Poetry conveys the meaning more clearly when it is read and heard (Vardell, 2003). Songs are not just notes, poetry is not just text. Poetry helps students make correct pronunciation and gain correct words with their general listening understanding (Bagert, 1992). Many students love the link between music and poetry. Basically, poems are matched to song tunes that contain the same counter. This musical connection with poetry makes poems unforgettable (Vardell, 2003: 210). Adding sound effects and background music to the poems, reading the poems with the styles of music they like, encourages students to think and read the poems they love better (Chatton, 1993; Ada, 1995: 32). Music is essentially educational. Almost all functions of music in human life are formed, changed, developed and competent only through education (music education). In this respect, everyone who is related to music is more or less related to the educational dimension of music (Uçan, 1996: 30). Gardner states that every person who comes together with music can be successful with some skills he has in musical activities such as composing, singing and playing instruments. In addition, Gardner (2006) stated that music is an inspiration for people and that people find peace with music. Gardner (2006) especially emphasized Mozart's music and stated how important his compositions were in the education of people. Therefore, it is thought that the students will better understand the events described through the education that will be carried out using music in schools.

The module is a program unit that takes part in the curriculum of various professions and forms a whole within that program, has a transferable content and has the feature of having broader professional functions by integrating with other curriculums. Modules give individuals various competencies. The fact that the curriculum consists of various modules is also modular teaching. Each module helps the individual gain knowledge, skills and attitudes. In addition, modular programs are formed by following the modules in a certain order and grouping them as a whole (SVET, 2006: 79). Modular teaching, which is a student-centered learning and teaching approach within the framework of constructivist approach, constitutes a whole system within the framework of modular programs. This system is the integration of modules into training programs. The module consists of learning-teaching activities consisting of individual teachings that follow a certain order and teaching experiences that show systematic integrity (Karadeniz, 2008: 35; Alkan, 1997: 197). 
Consequently, modular teaching is a teaching approach that gives opportunities to learn and improve itself in line with the individual's own life, by analyzing certain systematic ways in education and training (Külahçı \& Taşpınar, 1993: 24). According to Alkan (1989), the modular teaching approach has the following basic characteristics:

- The content of the program can be arranged flexibly, which can be applied to different situations and needs of individuals.

- Individuals are given the chance to choose according to their interests and wishes.

- It is possible to switch between different programs.

- Enables individual education.

- There is an opportunity to switch between formal and non-formal education institutions.

- It brings a different understanding to educational practices.

- It is possible to apply modular instruction in pre-service and in-service training.

- It is possible to adapt the prepared learning modules to systems such as computer aided education and distance education.

- It can be used effectively in the evaluation of education in different times and in different situations in a degree or diploma program. Especially in the vocational and technical education system, it has an effective function such as accelerating workforce education, providing continuous education, on-the-job training and selftraining opportunities, expanding the system, adapting technological developments, strengthening the relations between education and employment, raising quality and standards.

When the features of the modular teaching method are analyzed in general, it is seen that this teaching method has a contemporary structure like new teaching methods. It is an important teaching method both in terms of having a flexible program content and providing opportunity to switch between programs, as well as being applied to different education programs and enabling individual education (Kaykı, 2008: 14). In this study, by considering these features of the modular teaching method, an exemplary module with poetry and music was created. In addition, teachers' opinions about different teaching methods and modular teaching methods were determined.

\subsection{The importance and purpose of the research}

In this study, there are opinions of teachers about education that can be made to students by using poetry and music. As mentioned, poetry and music are part of human life. Therefore, every student will encounter these species throughout their life. For this reason, thanks to the education made by using music and poetry, what is wanted to be transferred to the student will be transferred more quickly and these gains will remain in the student's mind for a longer time. Music and poetry are a way of expressing thoughts, thoughts are a structure made of language and sounds. Musical and poetic expression can only be expressed in the language of music and poetry. Because the music is the common language of the human, the bases of universal culture are created by understanding the child's own country and the communities living in other countries and their cultures (Uçan, 1997: 133). When this universal quality of music is considered, the importance of education with music becomes clear once again.

In education with music, students will be more active than teachers. The student will be able to grasp the subject to be explained at the end of the lesson and make inferences about that subject. Therefore, it is thought that the Process Based Learning-Teaching Model is a suitable 
method for this application. Because this model, the planned execution of teaching in the teachinglearning process improves the students' awareness and use of cognitive awareness or cognitive awareness strategies. It is known that the active participation of the student in the teaching processes increases the learning levels and the permanence of what is learned. Because activating the student more in the teaching-learning process leads to a more effective, meaningful, efficient and more permanent learning experience (Duman, 2007: 56-57).

The features of this model are as follows (Duman, 2007: 43-44):

- Suggests to concentrate in the process of meeting and thinking, transfer the process knowledge and regulate the process and the training and education of the awareness of the process awareness.

- It is a critical, creative, planning and problem-based thinking model that offers the student to plan how to learn independently, to make decisions, to solve problems, to learn by self-directed learning, and to develop their skills.

- Explain how the teacher facilitates teaching, how to plan, and systematically describes how to provide versatile, multi-dimensional and multi-interactive environments according to the planning process.

- CSO has a functional feature such that both the teacher and the student have methods and strategies.

- Process-based teaching is a process-based and interactive program model that embraces social and classroom democratic values and attitudes.

- It is student centered. Responsibility for learning, decision-making is the student, adopts cognitive and constructive learning theories, the teacher performs the coaching and guidance task that facilitates teaching, content teaching is about how, why and how to acquire and structure information rather than storing information.

- Admits that knowledge is structured by the student himself through conceptual framework and mental models through the best experiences and activities.

The aim of the research is to determine the views of social studies teachers about the use of poetry and music as a module in social studies education and to present an exemplary module. For the purpose of the research, answers to the following questions were sought:

(1) What are the opinions of social studies teachers about modular teaching?

(2) Do social studies teachers use different methods besides the methods known in their lessons? What are these methods if they are using?

(3) Do social studies teachers use poetry and music as modules in their lessons? If they do, how do they include these modules in their lessons?

(4) What are the opinions of social studies teachers regarding the use of poetry and music as a module?

\section{Method}

Qualitative data collection tools were used in the study and descriptive and content analysis method was used in the analysis of qualitative data. Analyzes were made according to the principles and rules of descriptive and content analysis method. In addition, the qualitative data were analyzed according to the data obtained from the interview form applied to the teachers. A framework was formed by examining the data obtained from the teachers and it was determined which themes were to be arranged according to the themes. 


\subsection{Study group}

The research has been conducted to social studies teachers in the randomly selected secondary schools in the province of Nevssehir in the academic year 2016-2017. The information of these teachers is as in Table 1 below:

Table 1. Teachers in the research

\begin{tabular}{|ccclc|}
\hline Teacher & Gender & Age & Department & $\begin{array}{c}\text { Professional } \\
\text { Seniority }\end{array}$ \\
\hline Teacher 1 & Female & 26 & Social Studies & 2 \\
\hline Teacher 2 & Female & 30 & Social Studies & 4 \\
\hline Teacher 3 & Female & 29 & Social Studies & 5 \\
\hline Teacher 4 & Female & 28 & Social Studies & 4 \\
\hline Teacher 5 & Female & 27 & Social Studies & 3 \\
\hline Teacher 6 & Male & 29 & Social Studies & 4 \\
\hline Teacher 7 & Male & 31 & Social Studies & 6 \\
\hline Teacher 8 & Male & 28 & Social Studies & 4 \\
\hline Teacher 9 & Male & 29 & Social Studies & 3 \\
\hline Teacher 10 & Male & 28 & Social Studies & 4 \\
\hline
\end{tabular}

\subsection{Data collection tool and data analysis}

The data were collected by interview technique. In this study, semi-structured interview form was prepared by field experts and was used as data collection tool. In addition, other field experts were consulted for the validity of the form. Data were analyzed using descriptive and content analysis methods. Categorical analysis technique was used in content analysis. In addition, the qualitative data were quantified and the reliability was increased, internal credibility was increased by making direct quotations from the interviews and it was aimed to explain the views of the teachers by giving examples of the teachers' opinions on the questions. Descriptive analysis consists of the following four stages (Altunışı et al., 2010):

(1) Creating a framework for descriptive analysis,

(2) Processing of data according to the thematic framework,

(3) Identification of the findings,

(4) Interpretation of findings.

Categorical analysis technique was used in content analysis. The data were first coded in the content analysis. As a result of examinations on the data obtained, these were divided into meaningful sections. It was found out what each episode expresses conceptually. The stage of finding the categories and themes that emerged after the coding of the data was started. At this stage, the codes were categorized. Then the codes were explained in understandable language. In other words, the data was organized and defined according to the codes and themes in general. In addition, the qualitative data were digitized in the study and reliability was increased by direct quotations from the interviews, and internal reliability was increased, and it was aimed to explain the opinions of the teachers better by giving examples from the teachers' views on the questions. According to Ylldırım and Şimşek (2008), qualitative data can also be expressed with numerical values like quantitative data. For this reason, the qualitative data in this study also used numerical values. 
A. Durmaz - Teachers' Opinions on Alternative Approaches in Social Studies Education: Poetry...

\section{Results}

This section includes the views of social studies teachers on the use of poetry and music as a module in social studies education.

\subsection{Social studies teachers' opinions about alternative methods}

In order to determine the opinions of social studies teachers against alternative methods, the teachers first asked the questions: "What do you think are alternative methods? Can alternative methods be used in social studies lesson? What are these methods if they are using it?". When the answers given by the teachers regarding these questions are examined, it is seen that the teachers do not have information about alternative methods. When it comes to teachers as an alternative method, they first think of the school curriculum and the wrongness of the current education system. It is seen that teachers who think that the current education system is wrong do not know alternative methods. It was determined that what some teachers said as an alternative is not a method. As a matter of fact, it is seen that social studies teachers cannot go out of the existing system and cannot use / use alternative methods because the existing classes are not suitable for different methods. However, "Can alternative methods be used in the social studies course?", when the answers of the question were examined, most of the teachers stated that alternative methods were suitable for social studies lesson and different methods should be used in social studies lesson. In addition, it is seen that all of the teachers actively use the questionanswer technique in their classrooms. Apart from this, it was determined that some teachers also made school trips to help their students understand the subjects better. Some of the answers given by some teachers to the questions are as follows:

T3: I don't know much about alternative methods. But existing systems can be changed. Apart from this, different methods can be used easily in the social studies course. However, these methods should be such that the student can understand the lesson more easily.

T7: I do not think that the current curriculum of the social studies course is very suitable for different methods. If this curriculum and system are changed, lessons can be handled more easily if class sizes are reduced and teachers can use different methods more. Currently, even if teachers want, they cannot use different methods. Because the system does not allow this.

T10: I do not think that the system we are currently using is suitable for different methods. Because there are serious problems about time and even the lesson we teach with students in the form of questions and answers is difficult to catch up. For different methods, either lesson hours should be increased or subjects should be spread more.

\subsection{Social studies teachers'opinions on using poetry and music as a module}

In order to determine the opinions of social studies teachers about the use of poetry and music as a module, they said to teachers, and "Do you use poetry and music as modules? If you are, how do you include these modules in your lessons?", "Can poetry and music be used in social studies lessons as an alternative method? If used, how would you reflect this on the lesson?" questions were asked. When the answers received in line with these questions were examined, it was found that none of the teachers used poetry and music in their lessons. The reason for this is that teachers do not have enough time in the lesson. However, they stated that they could use poetry and music as an alternative method if they had enough time. Because they think that with poetry and music, students will be more interested in lessons and lessons will be more enjoyable for them. They also stated that the lessons taught in this way would be more permanent for the 
student. Several of the teachers are worried that the lessons that will be taught in this way will take a long time and that the subjects cannot be trained. However, they also stated that this situation could be prevented thanks to a planned time management. Teachers presented different opinions on how poetry and music can be used as a module in social studies lesson. For example, S1: Poetry and music can be used in social studies. It would be even more beautiful if used. In this way, students' lessons are enjoyable and many students actively participate in the lesson. For example, we can turn the topics into songs with a certain melody and present them to the students. In this way, when a question about that subject comes up, the student immediately remembers that song and it becomes easier to remember, and stated that the subjects should be presented by integrating them with music. Again, some of the social studies teachers' views on the use of poetry and music as a module are as follows:

T4: Frankly, I am not actively using poetry and music in my classes. I only benefit from them if there is poetry in the books of national education. Apart from that, I have no idea how I can use these methods even if I want to use them. More precisely, we do not have any material for these. Also, there is a shortage of time in lessons and I am not sure if time is enough in lessons taught in this way. However, I think that if such methods are included in the lessons, the students will understand the topics better. Because I think that the lesson taught with music will attract the attention of every student.

T6: I use not poetry but sometimes poetry in my classes. But they are not the poems I want. We read some of the poems in the curriculum (in the book) together with the students in the class and try to put forward their main idea. In the lessons, we usually teach with students in the form of questions and answers. In this way, I try to ensure students' participation in the class. However, teaching lessons with poetry and music can be more fun and permanent for students. Because music is something that most students love. I think that if we use the music in the lesson, the number of students attending the lesson increases. However, I do not have a clear idea about how the lessons will be transferred with poetry and music. If national education brings such activities to us, we apply it in our lessons.

\section{Discussion}

The literature scans carried out also support the findings obtained. Plato (1963) emphasized that music can be a part of primary education and can be used to describe historical events. Çencen and Berk (2014) stated in their studies that the use of poetry in lessons can improve students' empathy, creativity and questioning skills. They also emphasized that poetry, a literary product, can be used as a teaching material in order to gain affective skills. Again, Ceylan (2008) emphasized the importance of using poetry in terms of providing a fun, interesting and studentcentered educational environment in foreign language teaching. Önkaş (2013) emphasized the importance of using poetry in education and stated that the fluid and toned sounds in poetry are more than toneless sounds, and the connection between positive emotion and melodic voice will be made easier. In his studies, Şendurur and Barış (2002) emphasized that a proper and conscious music education should be given at every stage of the child's developmental stages and the importance of sensory education.

Again, considering the findings obtained in this study, there are some concerns about teachers' use of poetry and music in their lessons. Considering the findings obtained, teachers mostly use the question-answer technique in their lessons. Apart from this technique, it was determined that the student was more active and the methods and techniques that the student would make an inference in the taught lesson were not included in the lessons. The teachers stated that this was due to the current system of the Ministry of National Education and the low duration of the lessons. 


\section{Conclusions}

Many alternative methods are recommended for use in social studies. These alternative methods include poetry and music. Because the individual has been involved with music since his childhood, and he has been acquainted with poetry from his earliest years. Therefore, students are not alien to these concepts. Therefore, poetry and music can be used as an alternative approach in social studies education. Surveys, researches, articles and book reviews support this view. Therefore, it is thought that poetry and music will be used as an alternative method in social studies course. This research reflects the opinions of teachers in some secondary schools in the province of Nevşehir in order to determine the views of social studies teachers about the use of poetry and music as a module in social studies education and to present a model module. Based on the opinions of the teachers, the applicability of poetry and music to the social studies course has been put forward. The studies and the findings show that the opinions of the teachers on the use of poetry and music in the social studies course are positive. Literature scans have also supported the findings. However, there are some concerns that teachers use in poetry and music classes. According to the findings, teachers use mostly question and answer technique in their lessons. Apart from this technique, it is determined that the students are more active and that the students do not place much in their lessons. The teachers stated that this was due to the current system of the ministry of education and the current duration of the courses.

\section{Acknowledgements}

This research did not receive any specific grant from funding agencies in the public commercial, or not-for-profit sectors.

The author declares no competing interests.

\section{References}

Ada, A. F. (1995). A chorus of cultures: Developing literacy through multicultural poetry. Carmel, Calif: Hampton-Brown Books.

Akkaş, S. (1993). Okulöncesi eğitimde müzik [Music in preschool education]. Ankara: Gazi Üniversitesi, Mesleki Eğitim Fakültesi.

Alkan, C. (1997). Eğitim teknolojisi [Education technology]. Ankara: Anı Yayıncılık.

Alkan, C. (1989). Modüler programlama ve Türkiye'de uygulama [Modular programming and its implementation in Turkey]. Ankara Üniversitesi Ĕ̆itim Bilimleri Dergisi, 22(1), 13-22.

Altunışık, R., Çoşkun, R., Yıldırım, E., \& Bayraktaroğlu, S. (2010). Sosyal bilimlerde araştirma yöntemleri [Research methods in social sciences]. 6. Baskı, Sakarya: Sakarya Kitabevi.

Arp, T. (1997). Perrine's sound and sense: An introduction to poetry, $9^{\text {th }}$ Ed. Fort Worth, TX: Hardcourt Brace College Publishers.

Bagert, B. (1992). Act it out: Making poetry come alive. Bernice Cullinan, Ed., Invitation to Read: More Children's Literature in the Reading Program.

Bağrıaçı, Z. (2019). Ortaöğretim öğrencilerine uygulanan müzik eğitimiyle ilgili olarak ebeveynlerin görüşlerinin değerlendirilmesi [Evaluation of parents' views on music education applied to secondary school students]. Pamukkale Üniversitesi Eğitim Bilimleri Enstitüsü. Yayımlanmamış yüksek lisans tezi. 
Ceylan, H. (2008). Yabancı dil olarak İngilizce'nin öğretiminde şiirin kullanimi. Trakya Üniversitesi [The use of poetry in teaching English as a foreign language]. Sosyal Bilimler Dergisi, 1O(1), 116-121.

Chatton, B. (1993). Using poetry across the curriculum. Phoenix, Ariz: Oryx Press

Çencen, N., \& Berk, N. (2014). Ortaöğretim T. C. inkilâp tarihi ve Atatürkçülük dersinde "şiir kullanimina" ilişkin öğretmen görüşleri [Teachers' opinions on "the use of poetry" in the Republic of Turkey, Turkish Revolution history and Kemalism course]. Turkish History Education Journal, 3(1), 1-23. http://doi.org/10.17497/tuhed.185592

Donaldson, P. D. (2001). Teaching geography's four traditions with poetry. Journal of Geography, 10o(1), 24-31

Duman, B. (2007). Süreç temelli öğrenme öğretim modeli [Process-based teaching and learning model]. Muğla Üniversitesi Sosyal Bilimler Enstitüsü Dergisi (İlke) Sayı: 19. Muğla.

Gardner, H. (2006). Eğitimli akıl [Educated mind]. İstanbul: Morpa yayınları.

Karadeniz, O. (2008). Endüstri meslek liseleri elektrik elektronik teknolojileri alaninda uygulanmakta olan modüler öğretim yöntemi ile geleneksel öğretim yönteminin öğretmen görüşleri çerçevesinde karşılaştırılması (Yeditepe Üniversitesi Sosyal Bilimler Enstitüsü Yüksek Lisans Tezi) [Comparison of the modular teaching method applied in the field of electrical and electronic technologies in the industrial vocational high schools with the traditional teaching method within the framework of teachers' opinions (Yeditepe University Institute of Social Sciences Master Thesis)]. İstanbul.

Kaykı, İ. E. (2008). Modüler öğretim yöntemi ve uygulamalı dersler. Yayımlanmamış Yüksek Lisans Tezi [Modular teaching method and practical lessons. Unpublished Master Thesis]. İstanbul: Beykent Üniversitesi Sosyal Bilimler Enstitüsü.

Kutlu, B. (2019). Antik Yunan kültüründe müziğin kullanım alanları ve 20. yüzyıldan günümüze etkileri [Usage areas of music in Ancient Greek culture and its effects from the $2 \mathrm{O}^{\text {th }}$ century to the present]. Sosyal Bilimler ve Eğitim Dergisi, 2(2), 300-310.

Külahçı, Ş. G., \& Taşpınar, M. (1993). Modüler öğretim yaklaşımı ve Fırat üniversitesinde yapılan çalışmalar [Modular teaching approach and studies at Frrat University]. Eğitim ve Bilim, 17(90), 24-34. Ankara.

McCall, A. L. (2004). Using poetry in social studies classes to teach about cultural diversity and social justice. The Social Studies. July/August.

Meadows, D. M. (1999). African-American poetry and history: Making connections. OAH Magazine of History, 13, 36-41.

MEGEP (2006). Öğretim Programları ve Modüler Öğretim Uygulama Kılavuzu [Curriculum and modular instruction practice guide].

Önkaş, N. (2013). Klâsik şiir örneklerinin Türkçe eğitiminde kullanilmasi üzerine bir çalişma [A study on the use of classical poetry samples in Turkish education]. Hacettepe Üniversitesi Ĕ̆itim Fakültesi Dergisi, 28(28-1), 1-14.

Plato (1963). Republic, in The Collected Dialogues of Plato. Princeton: Princeton University Press

Sidekli, S., Yangın, S., \& Gökbulut Y. (2007). 5. Sınıf sosyal bilgiler dersinde şiirle öğretim yöntemine örnek bir uygulama [An example of application to teaching method with poetry in classroom social studies course]. VI. Sinıf Öğretmenliği Ĕ̆itimi Sempozyumu. Anadolu Üniversitesi, Eskişehir

Şen, Y., (2010). Okulöncesi dönemde, çocuğun gelişiminde müziğin önemi [The importance of music for child's development in preschool period]. Atatürk Üniversitesi Sosyal Bilimler Enstitüsü Dergisi, 7(1), 337-343.

Şendurur, Y., \& Barış, D. A. (2002). Müzik eğitimi ve çocuklarda bilişsel başarı [Music education and cognitive success in children]. Gazi Üniversitesi Gazi Ĕ̈itim Fakültesi Dergisi, 22(1).

Tanrıkorur, C. (2003). Müzik kültür dil [Music culture language]. İstanbul: Dergah Yayınları. 
A. Durmaz - Teachers' Opinions on Alternative Approaches in Social Studies Education: Poetry...

Uçan, A. (1997). Müzik eğitimi temel kavramlar-ilkeler-yaklaşımlar [Music education basic conceptsprinciples-approaches]. Ankara: Müzik Ansk. Yay. Adalet Matbaası.

Uçan, A. (1996). İnsan ve müzik - insan ve sanat eğitimi [Human and music - Human and art education]. Ankara: Müzik Ansk. Yay., Alf Matbaası.

Vardell, S. M. (2003). Poetry for social studies: Poems, standards, and strategies. Social Education, 67(4), 206-211.

Yardımcı, M. (1999). Başlangıcından günümüze halk şïri aşık şïri tekke şïri [Folk poetry, love poetry, and tekke poetry, from the beginning to the present]. Ankara: Ürün Yayınları.

Yıldırım, A., \& Şimşek, H. (2008). Sosyal bilimlerde nitel arastirma yontemleri [Qualitative research methods in the social sciences]. Ankara: Seçkin Yayınları.

Yöre, S. (2004). Türkiye'de çocuk müziği [Children's music in Turkey]. Çoluk Çocuk Dergisi Sayı, 45. 